\title{
FAKTOR - FAKTOR KECEMASAN SISWA DALAM PEMBELAJARAN JARAK JAUH DI MASA PANDEMI COVID-19
}

\author{
Harum Fitriyani, Muhammad Arif Budiman Sucipto
}

\author{
Universitas Pancasakti Tegal
}

\begin{abstract}
Abstrak
Pandemi Covid-19 menyebabkan berbagai banyak perubahan, terutama perubahan pada bidang pendidikan, pembelajaran yang seharusnya dilakukan tatap muka dengan adanya covid-19 menjadi pembelajaran jarak jauh. Hal tersebut yang menjadikan siswa mengalami banyak perubahan dan penyesuaian yang menyebabkan siswa mengalami kecemasan. Tujuan penelitian ini adalah untuk mengetahui faktor kecemasan siswa dalam pembelajaran jarak jauh di masa pandemic covid 19 di SMK 01 Pusponegoro Kabupaten Brebes. Jenis penelitian ini adalah penelitian kuantitatif deskriptif. Subjek pada penelitian ini adalah siswa kelas X Jurusan Teknik Kendaraan Ringan dengan jumlah 40 orang. Pengumpulan data menggunakan kuesioner yang berjumlah 50 item. Teknik pengumpulan data menggunakan metode survey menggunakan angket kuesioner. Kuesioner berisi pernyataan yang disertai dengan pilihan yaitu Sangat Setuju, Setuju, Tidak Setuju, Sangat Tidak Setuju. Teknik analisis data menggunakan norma kategorisasi distribusi normal. Hasil Penelitian menunjukan bahwa terdapat faktor internal dan eksternal yang mempengaruhi kecemasan yaitu pola pikir tentang kesulitan berkonsentrasi pada saat pembelajaran online dan faktor cuaca. Hal tersebut dapat diatasi dengan menyesuaikan pembelajaran melalui online atau daring sehingga mampu dapat berkonsentrasi dengan baik pada saat pembelajaran.
\end{abstract}

Kata Kunci : Kecemasan, Pembelajaran Jarak Jauh, Pandemi Covid-19

\begin{abstract}
The Covid-19 pandemic has caused many changes, especially changes in the field of education, learning that should have been done face-to-face with COVID-19 has become distance learning. This makes students experience many changes and adjustments that cause students to experience anxiety. The purpose of this study was to determine the factors of student anxiety in distance learning during the covid 19 pandemic at SMK 01 Pusponegoro, Brebes Regency. This type of research is descriptive quantitative research. The subjects in this study were students of class X, Department of Light Vehicle Engineering with a total of 40 people. Collecting data using a questionnaire totaling 50 items. The data collection technique used a survey method using a questionnaire questionnaire. The questionnaire contains statements accompanied by choices, namely Strongly Agree, Agree, Disagree, Strongly Disagree. The data analysis technique uses the normal distribution categorization norm. The results of the study show that there are internal and external factors that affect anxiety, namely thinking patterns about difficulty concentrating during online learning and weather factors. This can be overcome by adjusting learning through online or online so that they are able to concentrate well during learning.Key: Montessori method, child development, child guidance and counseling

Key : Anxiety, Distance Learning, Covid-19 Pandemic
\end{abstract}




\section{PENDAHULUAN}

Setiap orang ingin menjalani kehidupan yang tenang, damai tanpa adanya tekanan maupun paksaan dari orang-orang disekitarnya. Setiap orang ingin memiliki perasaan tenang maupun tentram dalam menjalani dalam setiap fase kehidupan. Setiap tahapan perkembangan manusia akan dihadapkan pada berbagai masalah dan dengan penanganan yang berbeda-beda. Masalah yang terjadi dapat menyebabkan maupun menimbulkan rasa sedih, jika tidak segera diatasi akan menimbulkan perasaan tertekan dalam diri seseorang. Begitu juga sebaliknya sesuatu yang menyenangkan mampu membuat seseorang merasa bahagia. Kesejahteraan psikologis yang baik akan berpengaruh terhadap kualitas hidup seseorang.

Indonesia mengalami Pandemi Covid-19 pada akhir tahun 2019, seluruh manusia di dunia mengalami kepanikan adanya pandemi Covid-19. Virus ini membuat manusia terinfeksi sampai meninggal dunia. Virus yang menyerang sistem pernapasan disebut dengan Virus Corona atau Severe Acute Respiratory Syndrome Coronavirus 2 (SARS-CoV-2). Berbagai aspek kehidupan mengalami perubahan akibat adanya pandemi COVID-19. Untuk mengurangi tingkat penyebaran virus corona pemerintah telah mengeluarkan berbagai kebijakan seperti sosial distancing, physical distancing hingga pemberlakuan PSBB (pembatasan social berskala besar) di berbagai daerah. Dengan adanya kebijakan yang dikeluarkan memiliki dampak pada berbagai bidang, khususnya pendidikan di Indonesia. Wabah ini mendesak pengujian pendidikan jarak jauh hampir yang belum pernah dilakukan secara serempak sebelumnya (Sun et al., 2020). Bagi semua elemen pendidikan seperti peserta didik, guru hingga orang tua perlu melakukan inovasi dan adaptasi terkait pemanfaatan teknologi yang tersedia untuk mendukung proses pembelajaran pada kondisi saat ini (Ahmed et al., 2020). Pembelajaran online dapat memanfaatkan platform berupa aplikasi, website, jejaring sosial maupun learning management system (Gunawan et al., 2020).

Pandemi di Indonesia mengalami keterbatasan dalam melakukan berbagai aktivitas, terutama dalam hal pendidikan. Kualitas hidup masyarakat Indonesia selama pandemi Covid-19 mengalami penurunan karena tidak baiknya kesejahteraan psikologis. Adanya pandemi Covid-19 ini sistem pembelajaran di Indonesia dilakukan secara online atau daring, pembelajaran daring ini disebut juga Pembelajaran Jarak Jauh (PJJ) maupun Pembelajaran Dari Rumah (BDR). Belajar dari Rumah (BDR) dilaksanakan dengan sistem Pembelajaran Jarak Jauh (PJJ). Dalam Undang-undang No. 20 tahun 2003 pasal 1 ayat 15 , pendidikan yang peserta didiknya terpisah dari pendidik dan pembelajarannya menggunakan berbagai sumber belajar melalui teknologi komunikasi, informasi dan media lain disebut dengan Pembelajaran Jarak Jauh. Dalam pelaksanaannya, ada dua pendekatan dalam PJJ, yaitu pembelajaran jarak jauh dalam jaringan (daring) dan pembelajaran jarak jauh luar jaringan (luring). Dalam pelaksanaan PJJ, satuan pendidikan dapat memilih menggunakan pendekatan (daring atau luring atau kombinasi keduanya) yang sesuai dengan Karakteristik, ketersediaan, kesiapan sarana dan prasarana. Adanya peraturan baru dalam sistem pendidikan mengenai pembelajaran jarak jauh mengakibatkan siswa mengalami berbagai macam perubahan, baik perubahan dari sistem pembelajaran nya maupun dalam hal proses belajar mengajarnya. Pada hasil penelitian pada siswa yang dievaluasi selama periode pandemi mengalami tingkat kecemasan, depresi, dan stres yang jauh lebih tinggi, dibandingkan dengan para siswa pada masa-masa normal (Hasanah, et al 2020). Pandemi memiliki efek psikologis negatif pada siswa.

Pelaksanaan sistem pembelajaran pada satuan pendidikan mengalami berbagai perubahan kebijakan pembelajaran dan mengikut pada kebijakan sosial, yaitu instruksi social distancing hingga berujung pada himbauan lockdown. Adanya kebijakan tersebut menimbulkan berbagai macam respon masyarakat, khususnya respon siswa dalam pemberlakuan pembelajaran jarak jauh. Pemberlakuan pembelajaran jarak jauh mengharuskan siswa dapat menyesuaikan dengan kondisi dan situasi di lingkungan sekitar, khususnya siswa harus dapat menyesuaikan dengan sistem pembelajaran jarak jauh tersebut. Pembelajaran jarak jauh mengakibatkan adanya kecemasan siswa. Pandemi Covid-19 siswa mengalami kecemasan terutama bila dihadapkan pada hal-hal yang baru maupun suatu konflik yang membutuhkan penyesuaian maupun adaptasi. Hampir semua orang mengalami kecemasan, hanya tingkatnya yang berbeda. Perasaan ketakutan dan keprihatinan berkaitan dengan masa depan tanpa adanya sebab khusus disebut kecemasan. 
Standar Nasional Pendidikan sesuai yang tercantum dalam Peraturan Pemerintah Nomor 19 Tahun 2005 adalah standar penilaian pendidikan. Standar nasional pendidikan yang berkaitan dengan mekanisme, prosedur, dan instrumen penilaian hasil belajar peserta didik merupakan standar penilaian pendidikan. Sesuai dengan kebijakan dari Kementerian Pendidikan dan Budaya Indonesia, komunikasi yang biasanya dilakukan secara langsung diganti dengan komunikasi berbasis digital atau online. Pada tanggal 17 Maret 2020 pemerintah mengeluarkan Surat Edaran dari Menteri Pendidikan dan Kebudayaan mengenai Pembelajaran secara daring dan bekerja dari rumah dalam rangka mencegah penyebaran Corona Virus Disease (COVID-19). Adanya sistem pembelajaran jarak jauh maupun penyelenggara belajar dari rumah menyebabkan siswa mengalami kecemasan. Hasil belajar siswa dipengaruhi kecemasan, karena kecemasan mengakibatkan kebingungan dan distorsi persepsi (Pamungkas 2020). Hal ini dapat mengganggu belajar seperti kemampuan maupun daya ingat menjadi menurun, dan yang lainnya.

Zulfia, et al (2021) mengatakan bahwa kecemasan merupakan keadaan khawatir yang mengatakan bahwa suatu hal yang buruk akan segera terjadi. Kekhawatiran atau kecemasan yang dapat mengganggu kesehatan mental siswa disebabkan karena adanya pembelajaran jarak jauh. Orang tua pun mengakui bahwa akibat tugas yang selama pembelajaran daring menyebabkan anak menjadi stress. Tugas yang terlalu banyak diberikan oleh pendidik akan membuat siswa merasa stres dalam menjalani pembelajaran online (Oktawirawan, 2020). Tugas yang diberikan pendidik juga dianggap memberatkan dan memiliki waktu pengerjaan yang sangat singkat sehingga membuat peserta didik kebingungan dalam menyelesaikan tugas (Barseli, et al 2020).

Faktor yang mempengaruhi kecemasan siswa yaitu faktor internal maupun faktor eksternal (Wakhyudin, 2020). Faktor internal disini adalah faktor yang memang timbul atau terjadi karena disebabkan oleh diri sendiri sedangkan faktor eksternal merupakan faktor yang terjadi di luar diri individu seperti faktor lingkungan dan lain sebagainya. Selama pandemi dapat menyebabkan gangguan kesehatan mental, seperti ketakutan terhadap wabah, kesedihan dan kesepian karena jauh dari keluarga atau orang yang dikasihi, kecemasan akan kebutuhan hidup sehari-hari, ditambah lagi kebingungan akibat informasi yang simpang siur atau tidak jelas. Hal ini tidak hanya berdampak atau terjadi pada orang yang telah memiliki masalah kesehatan mental, seperti gangguan kecemasan umum, namun juga dapat mempengaruhi pada orang yang sehat secara fisik dan mental. Masa pandemi, anak-anak menjadi kurang aktif karena tinggal di rumah saja. Tingkat kecemasan masyarakat Indonesia mengalami peningkatan semenjak adanya Covid-19, khususnya bagi para pelajar di Indonesia mengalami tingkat kecemasan dari adanya proses pembelajaran jarak jauh.

Penelitian ini memiliki tujuan untuk mengetahui faktor-faktor kecemasan siswa dalam pembelajaran jarak jauh ditengah pandemi covid-19. Dalam hal ini peneliti ingin mengetahui faktor apa saja yang menyebabkan siswa mengalami tingkat kecemasan dibandingkan sebelum adanya pandemi Covid-19. Peneliti juga ingin mengetahui faktor kecemasan yang paling banyak terjadi di kalangan siswa, apakah dari faktor internal atau faktor eksternal. Berdasarkan uraian diatas, peneliti tertarik untuk mengadakan penelitian mengenai faktor-faktor kecemasan siswa dalam pembelajaran jarak jauh ditengah pandemi Covid-19.

\section{METODE}

Dalam suatu penelitian metode hal yang sangat penting karena tanpa adanya metode penelitian yang dilakukan maka tidak dapat dipertanggung jawabkan secara ilmiah. Berdasarkan permasalahan yang akan diteliti maka di dalam penelitian ini peneliti menggunakan metode deskriptif kuantitatif. Penelitian yang digunakan untuk mengumpulkan informasi mengenai status suatu gejala yang ada yaitu keadaan segala menurut apa adanya pada saat penelitian dilakukan disebut dengan penelitian deskriptif ( Arikunto, 2008 : 190) Adapun sifat atau ciri yang dimiliki metode deskriptif seperti memusatkan diri pada masalah yang aktual dan data yang dikumpulkan awalnya disusun, dijelaskan kemudian dianalisis. Pada umumnya penelitian deskriptif berasal dari data yang dikumpulkan melalui angket dan observasi sebagai pelengkap pengumpulan data dalam suatu penelitian. Dalam penelitian ini yaitu mengenai faktor-faktor kecemasan siswa dalam pembelajaran jarak jauh ditengah pandemi Covid-19. Penelitian ini dilakukan di SMK 
Pusponegoro 01 Brebes Kabupaten Brebes Provinsi Jawa Tengah. Subjek Penelitian yaitu siswa SMK Pusponegoro 01 Brebes, kelas X jurusan TKR (Teknik Kendaraan Ringan). Keterbatasan jumlah subjek maka peneliti mengambil semua jumlah subjek penelitian yang berjumlah 40 orang. Teknik pengumpulan data menggunakan metode survey menggunakan angket kuesioner. Kuesioner berisi pernyataan yang disertai dengan pilihan yaitu Sangat Setuju, Setuju, Tidak Setuju, Sangat Tidak Setuju. Teknik analisis data menggunakan norma kategorisasi distribusi normal.

\section{HASIL DAN PEMBAHASAN}

Hasil data yang diperoleh dari penyebaran angket sejumlah 40 orang siswa di SMK Pusponegoro 01 brebes memperoleh hasil faktor internal dan eksternal kecemasan siswa dalam pembelajaran jarak jauh ditengah pandemi Covid-19 yaitu berdasarkan hasil penelitian yang telah dilakukan peneliti dengan pengumpulan data secara angket banyak terdapat faktor yang menyebabkan kecemasan pada siswa dalam pembelajaran jarak jauh. Pada faktor internal subitem pola berpikir khususnya pernyataan yang menyatakan "saya sulit berkonsentrasi pada saat pembelajaran online", hal ini merupakan penyebab internal yang sering terjadi pada kecemasan peserta didik. Adapun hasil dari angket tersebut yang telah disebarkan dan diisi oleh responden adalah sebagai berikut :

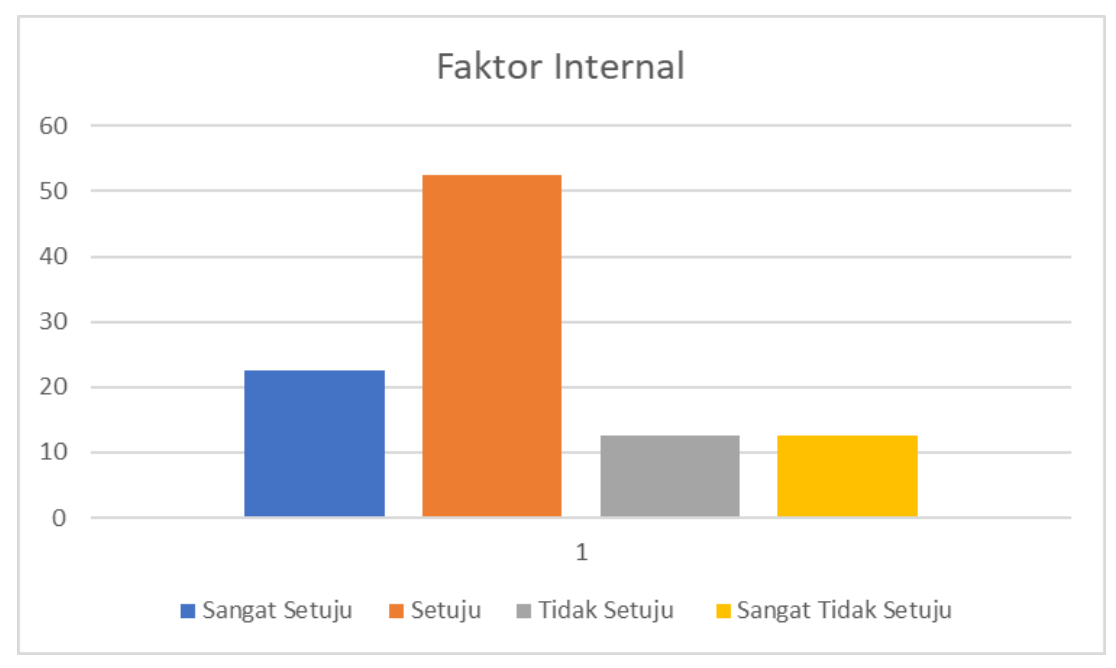

\section{Gambar 1. Faktor Internal}

Pernyataan tersebut dengan jawaban setuju 52,5 \% kategori sangat dominan dengan jumlah responden 21 siswa, sangat setuju 22,5\% kategori dominan dengan jumlah responden 9 siswa, tidak setuju $12,5 \%$ kategori kurang dominan dengan jumlah responden 5 siswa, dan sangat tidak setuju 12,5\% kategori sangat kurang dominan dengan jumlah responden 5 siswa. Dari uraian diatas, disimpulkan bahwa kecemasan siswa yang terjadi karena sulit berkonsentrasi pada saat pembelajaran online dikategorikan sangat dominan yaitu pada jawaban setuju sebanyak $52,5 \%$.

Faktor eksternal kecemasan siswa dalam pembelajaran jarak jauh ditengah pandemi Covid-19. Berdasarkan hasil penelitian di SMK Pusponegoro 01 Brebes yang telah dilakukan peneliti dengan pengumpulan data secara angket banyak terdapat faktor yang menyebabkan kecemasan pada siswa dalam pembelajaran jarak jauh. Pada faktor eksternal yang sering terjadi pada peserta didik terdapat pada sub item faktor lingkungan / cuaca, pada pernyataan yang menyatakan "Saya lebih setuju ketika proses pembelajaran online dilaksanakan pada siang hari". Adapun hasil dari angket yang telah diisi oleh responden sebagai berikut : 


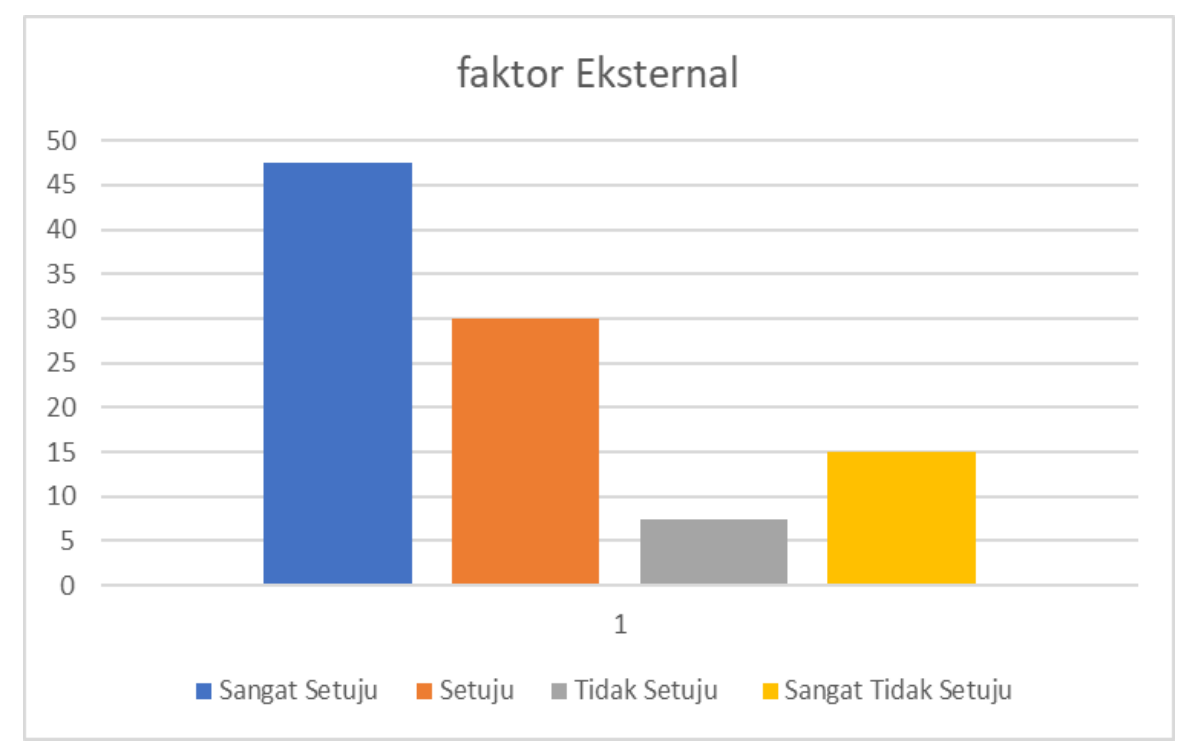

Gambar 2. Faktor Eksternal

Pernyataan dengan jawaban sangat setuju 47,5 \% kategori sangat dominan dengan jumlah responden 19 siswa, setuju $30 \%$ kategori dominan dengan jumlah responden 12 siswa, sangat tidak setuju $15 \%$ kategori kurang dominan dengan jumlah responden 6 siswa, dan jawaban tidak setuju 7,5\% kategori sangat kurang dominan dengan jumlah responden 3 siswa. Dari uraian diatas, disimpulkan bahwa kecemasan siswa yang terjadi karena faktor cuaca atau lingkungan dengan pernyataan lebih setuju ketika proses pembelajaran online dilaksanakan pada siang hari dikategorikan sangat dominan yaitu pada jawaban sangat setuju sebanyak $47,5 \%$.

Berdasarkan hasil temuan peneliti maka dapat disimpulkan bahwa terdapat 2 faktor kecemasan siswa dalam pembelajaran jarak jauh di tengah pandemi Covid-19 yaitu faktor internal dan faktor eksternal. Terdapat lima jenis penyebab kecemasan pada faktor internal dan terdapat lima jenis penyebab kecemasan pada faktor eksternal. Dari kelima penyebab kecemasan yang terdapat pada faktor internal didapatkan hasil bahwa faktor dari cara berpikir merupakan faktor yang sering terjadi pada siswa SMK Pusponegoro 01 Brebes. Adapun faktor dari cara berpikir yaitu bahwa siswa sulit berkonsentrasi pada saat pembelajaran online.

Siswa SMK Pusponegoro 01 Brebes lebih fokus pada saat pembelajaran di dalam kelas atau offline daripada pembelajaran daring, karena pada saat pembelajaran daring fokus siswa terbagi-bagi antara mata pelajaran, kondisi atau keadaan rumah maupun kondisi sinyal. Sedangkan pada faktor eksternal, dari kelima penyebab kecemasan yang terdapat pada faktor eksternal didapatkan hasil bahwa faktor dari lingkungan atau cuaca merupakan faktor yang sering dirasakan pada siswa SMK Pusponegoro 01 Brebes. Adapun faktor dari lingkungan atau cuaca seperti susah sinyal pada saat cuaca tidak mendukung seperti hujan, hal ini yang sangat sering terjadi pada siswa SMK Pusponegoro 01 Brebes. Selain dari faktor cuaca, kondisi lingkungan juga menjadi penyebab kecemasan siswa dalam pembelajaran jarak jauh di tengah pandemi Covid-19, pada saat lingkungan rumah dalam kondisi ramai maka akan menyebabkan kecemasan, karena jika keadaan rumah dalam kondisi ramai maka akan mengganggu fokus maupun konsentrasi pada saat proses pembelajaran. Dari kedua faktor tersebut baik itu faktor internal maupun eksternal memiliki penyebabnya masing-masing. Tetapi pada siswa SMK Pusponegoro 01 Brebes mayoritas siswanya mengalami kecemasan pada faktor internal dikarenakan pola atau cara berpikir dan pada faktor eksternal dikarenakan lingkungan atau cuaca. 
Faktor internal maupun faktor eksternal dapat diatasi dengan berbagai cara yaitu yang pertama bahwa kita sebagai pelajar harus bisa menyesuaikan pembelajaran melalui online atau daring, kita sebagai pelajar harus dapat beradaptasi dengan proses pembelajaran yang baru, dengan kita dapat menyesuaikan maupun dapat beradaptasi maka kita dapat memahami mengenai proses pembelajaran daring tersebut serta kita dapat melakukan proses pembelajaran daring dengan penuh konsentrasi atau fokus. Ketika kita dapat menyesuaikan dan dapat berkonsentrasi maka akan fokus pada saat proses pembelajaran daring tersebut. Selain itu kita juga dituntut tidak hanya dalam penyesuaian proses pembelajarannya saja tetapi juga harus dapat menyesuaikan dengan kondisi atau keadaan yang ada disekitar kita termasuk lingkungan atau cuaca, pada saat proses pembelajaran daring sering kali kita terhambat dengan adanya gangguan sinyal. Dengan adanya gangguan sinyal tersebut menghambat dalam proses pembelajaran, biasanya kendala sinyal dikarenakan faktor cuaca yang tidak mendukung seperti hujan.

\section{SIMPULAN}

Berdasarkan hasil dan pembahasan dapat disimpulkan hal yang menjadi dasar pokok dalam penelitian Faktor Kecemasan Siswa Dalam Pembelajaran Jarak Jauh di SMK 1 Pusponegoro Kabupaten Brebes yaitu faktor internal dan faktor eksternal. Faktor internal yang sering muncul yaitu sulit berkonsentrasi pada saat pembelajaran online, sedangkan faktor internal yang sering muncul yaitu cuaca atau sinyal. Pelaksanaan Pembelajaran jarak jauh perlu memperhatikan faktor internal dan ekternal dari siswa supaya proses pembelajaran dapat berjalan efektif.

\section{DAFTAR PUSTAKA}

Ahmed, S., Shehata, M., \& Hassanien, M. (2020). Emerging Faculty Needs for Enhancing Student Engagement on a Virtual Platform. MedEdPublish, 9(1), 1-5. https://doi.org/10.15694/mep.2020.000075.1

Arikunto, S. 2008. Prosedur Penelitian Suatu Pendekatan Praktik. Jakarta : Rineka Karya

Barseli, M., Ifdil, I., \& Fitria, L. (2020). Stress akademik akibat Covid-19. JPGI (Jurnal Penelitian Guru Indonesia), 5(2), 95-99.

Gunawan, Suranti,N.M.Y., \& Fathoroni. (2020). "Variations of Models and Learning Platforms for Prospective Teachers During the COVID-19 Pandemic Period." Indonesian Journal of Teacher Education 1, no. $2: 61-70$.

Hasanah, Uswatun., Ludiana., Immawati., \& Livana. (2020). Gambaran psikologis mahasiswa dalam proses pembelajaran Selama pandemi covid-19. Jurnal Keperawatan, 8(3), 299-306

Oktawirawan, D. H. (2020). Faktor pemicu kecemasan siswa dalam melakukan pembelajaran daring di masa pandemi covid-19. Jurnal Ilmiah Universitas Batanghari Jambi, 20(2), 541-544.

Pamungkas, A. (2020). Tipe Kepribadian Ektrovert-Introvert dan Kecemasan Mahasiswa pada masa Pandemi Covid-19. Syams: Jurnal Kajian Keislaman, 1(2), 36-42

Sun, L., Tang, Y., \& Zuo, W. (2020). Coronavirus pushes education online. Nature Materials, 19(6), 687687

Zulfia, I., Meilinda, M., Ilma, N., \& Muskhafiyah, S. (2021). Kesehatan Mental Remaja Pada Masa Pandemi. Counseling As Syamil, I (01), 11-19.

Wakhyudin, H., \& Putri, A. D. S. (2020). Analisis kecemasan mahasiswa dalam menyelesaikan skripsi. Wasis: jurnal ilmiah pendidikan, 1(1), 14-18. 